\title{
Analisis Kemampuan Pemecahan Masalah pada Materi Bangun Ruang Sisi Datar di Kelas IX
}

\author{
Pradita Unonongo ${ }^{*}$, Sumarno Ismail ${ }^{2}$, Kartin Usman ${ }^{3}$
}

\author{
1,2,3 Jurusan Matematika, Fakultas MIPA, Universitas Negeri Gorontalo, \\ Jl. Prof. Dr. Ing. B. J. Habiie, Tilongkabila, Kabupaten Bone Bolango, Gorontalo 96119, Indonesia
}

\begin{abstract}
INFO ARTIKEL
* Penulis Korespondensi.

Email:

punonongo@gmail.com

\section{Diterima:}

27 Mei 2021

Disetujui:

29 Juni 2021

Online

3 Juli 2021

Format Sitasi:

P. Unonongo, S. Ismail and K. Usman, "Analisis Kemampuan Pemecahan Masalah pada Materi Bangun Ruang Sisi Datar di Kelas IX," Jambura J. Math. Educ., vol. 2, no. 2, pp.43-49, 2021

Lisensi:

JMathEdu is licensed under a Creative Commons AttributionNonCommercial 4.0 International License

Copyright () 2021

Jambura Journal of Mathematics Education

\section{ABSTRAK}

Artikel ini membahas tentang kemampuan pemecahan masalah siswa pada materi bangun ruang sisi datar pada semester ganjil tahun pelajaran 2020/2021. Penelitian ini dilakukan di SMP Negeri 2 Gorontalo dengan melibatkan 35 orang siswa kelas IX sebagai subjek penelitian, yang dipilih dengan menggunakan teknik pengambilan data purposive sampling. Pengumpulan data dilakukan menggunakan tes berupa soal cerita untuk mengukur kemampuan pemecahan masalah dan wawancara untuk memperkuat dan menambah informasi yang diperlukan. Indikator yang digunakan untuk mengukur kemampuan pemecahan masalah antara lain: 1) memahami masalah, 2) merencanakan penyelesaian, 3) menyelesaikan masalah, 4) memeriksa kembali hasil yang diperoleh. Hasil penelitian menunjukan bahwa capaian rata-rata tingkat kemampuan siswa dalam menyelesaikan soalsoal kontekstual di kelas IX SMP Negeri 2 Gorontalo masih dalam kategori rendah yaitu sebesar 53,51\% meskipun ada sebagian siswa yang mendapat skor tinggi. Hal ini ditunjukan dengan capaian indikator memahami masalah dengan presentase sebesar 44,86\%, indikator merencanakan penyelesaian mendapat presentase sebesar $61,14 \%$, indikator menyelesaikan masalah mendapat presentase sebesar $63,86 \%$ dan indikator memeriksa kembali hasil yang diperoleh mendapat presentase sebesar $43,62 \%$.

Kata Kunci: Kemampuan Pemecahan Masalah, Bangun Ruang Sisi Datar

ABSTRACT

This article discusses the problem-solving abilities of students in the flat-sided geometry material in the odd semester of the 2020/2021 school year. This research was conducted at SMP Negeri 2 Gorontalo involving 35 students of class IX as research subjects, who were selected using purposive sampling data collection techniques. Data collection was carried out using tests in the form of story questions to measure problem-solving abilities and interviews to strengthen and add the required information. Indicators used to measure problem-solving abilities include: 1) understanding the problem, 2) plan a solution, 3) solve the problem, 4) recheck the results obtained. The results showed that the average achievement of students' ability levels in solving contextual questions in class IX of SMP Negeri 2 Gorontalo was still in the low category, namely $53.51 \%$ although there were some students who got high scores. This is shown by the achievement of the indicator of understanding the problem with a percentage of $44.86 \%$, the indicator of planning for completion getting a percentage of $61.14 \%$, the indicator of solving the problem getting a percentage of $63.86 \%$ and the indicator re-checking the results obtained getting a percentage of $43.62 \%$.

Keywords: Problem-Solving Ability; Flat-sides Geometry
\end{abstract}




\section{Pendahuluan}

Pendidikan mengambil peranan penting di era globalisasi seperti saat ini. Keberhasilan peningkatan kualitas pendidikan tidak terlepas dari beberapa komponen dalam belajar mengajar baik guru, siswa, kurikulum, sarana dan prasarana maupun lingkungan. Begitupun peningkatan kualitas pendidikan matematika yang ada di sekolah. Tujuan pembelajaran matematika telah dinyatakan oleh Depdiknas nomor 22 tahun 2016 [1] bahwa di SD, SMP, SMA dan SMK pelajaran matematika ditujukan supaya peserta didik mempunyai kemampuan salah satunya memecahkan masalah, meliputi kemampuan memahami masalah, merancang model matematika, menyelesaikan model matematika dan menafsirkan hasil yang diperoleh. Sehingga pada pembelajaran matematika siswa diharapkan dapat mengembangkan kemampuan pemecahan masalah.

Kurangnya kemampuan pemecahan masalah yang dipunyai siswa merupakan salah satu dari beberapa faktor yang menyebabkan rendahnya hasil belajar. Khususnya di sekolah menengah pertama. Hal ini disebabkan oleh guru yang cenderung memberikan soal-soal dan tugas dengan bentuk yang monoton sehingga ketika siswa diberikan soal yang agak berbeda, mereka tidak bisa mengerjakan soal-soal tersebut. Hal ini pun disebabkan kurangnya strategi atau metode pembelajaran yang ditetapkan dalam proses belajar mengajar, sehingga mengakibatkan siswa menjadi sulit untuk mengembangkan kemampuan pemecahan masalah. Kemampuan pemecahan masalah tidak hanya mengharuskan siswa untuk menyelesaikan suatu masalah dengan cara yang disampaikan guru, tetapi lebih pada proses untuk menafsirkan kemampuannya [2]. Adapun salah satu usaha dalam meningkatkan kemampuan pemecahan masalah siswa yaitu dengan melatih siswa menyelesaikan soal-soal yang berhubungan dengan kehidupan sehari-hari. Terutama pada materi pelajaran bangun ruang sisi datar, dimana pada materi ini berkaitan dengan kehidupan sehari-hari sehingga dapat membantu siswa agar lebih mudah memahami isi dari soal yang diberikan. Kemampuan pemecahan masalah meliputi beberapa indikator diantaranya memahami masalah, merencanakan suatu penyelesaian, menyelesaikan masalah dan memeriksa kembali hasil yang diperoleh.

Berdasarkan hasil observasi, diperoleh informasi bahwa siswa memang tidak dilatih khusus untuk mengerjakan soal-soal pemecahan masalah maupun soal-soal yang berkaitan dengan lingkungan kehidupan sehari-hari. Guru banyak memberikan siswa soal-soal rutin yang hanya langsung mengaplikasikan rumus. Adapun pada materi bangun ruang sisi datar, materi ini cocok dikaitkan dengan kehidupan sehari-hari. Dengan memberikan soal-soal yang berkaitan dengan lingkungan sekitar sehingga perlahan dapat melatih kemampuan pemecahan masalah siswa.

Penelitian terkait dengan kemampuan pemecahan masalah siswa sejauh ini banyak dikaji oleh peneliti-peneliti seperti pada [3]-[5]. Juga dengan penelitian tentang upaya melakukan analisis terhadap kemampuan pemecahan masalah siswa yang terdapat pada [6]-[9]. Demikian pula dengan penelitian terkait pemecahan masalah siswa yang menggunakan indikator pemecahan masalah menurut Polya dapat dilihat pada [10][12]. Adapun penelitian yang berkaitan tentang materi pelajaran bangun ruang sisi datar dapat dilihat pada [13]-[16]. Dari beberapa penelitian yang telah disebutkan sebelumnya belum ada penelitian yang membahas secara khusus tentang kemampuan pemecahan masalah pada materi bangun ruang sisi datar. 
Pada makalah ini dilakukan analisis tentang kemampuan pemecahan masalah siswa pada materi bangun ruang sisi datar. Diharapkan dengan penelitian ini dapat memberikan informasi kepada guru, siswa maupun sekolah tentang kondisi kemampuan pemecahan masalah sehingga kedepannya dapat dikembangkan lagi.

\section{Metode}

Metode yang digunakan dalam penelitian ini adalah metode penelitian deskriptif untuk mendeskripsikan kemampuan pemecahan masalah matematika siswa pada materi bangun ruang sisi datar. Penelitian ini melibatkan siswa SMP Negeri 2 Gorontalo sebagai subjek penelitian. Sebjek pada penelitian ini berjumlah 35 orang siswa yang dipilih berdasarkan teknik pengambilan sampel purposive sampling. Seluruh sampel diberikan tes berbentuk essay yang memuat soal-soal kontekstual. Sebelum diberikan soal-soal tersebut telah diuji validitas dan reliabilitasnya terlebih dahulu. Kemudian data tes yang diberikan pada siswa dianalisis menggunakan analisis presentase.

$$
\text { Presentase }=\frac{\text { Jumlah Skor Perolehan }}{\text { Skor Maksimal }} \times 100 \%
$$

Untuk hasil yang diperoleh siswa akan dikategorikan berdasarkan apa yang mereka capai. Adapun kategori pengelompokan kategori tingkat kemampuan pemecahan masalah mengacu pada Tabel 1.

Tabel 1. Kategori tingkat kemampuan pemecahan masalah (\%)

\begin{tabular}{c|c}
\hline Persentase $(\%)$ & Kategori \\
\hline $65<\mathrm{P}<100$ & Tinggi \\
$56<\mathrm{P}<65$ & Sedang \\
$0<\mathrm{P}<56$ & Rendah \\
\hline
\end{tabular}

\section{Hasil dan Pembahasan}

\subsection{Hasil Penelitian}

Hasil penelitian yang ditunjukan melalui tes soal yang mengacu pada indikator kemampuan pemecahan masalah menurut Polya ditunjukan pada Tabel 2.

Tabel 2. Hasil Persentase presentasi kemampuan pemecahan masalah siswa berdasarkan indikator dan nomor soal

\begin{tabular}{cccccccc}
\hline Indikator & Soal 1 & Soal 2 & Soal 3 & Soal 4 & Soal 5 & Rata-Rata & Kategori \\
\hline 1 & $27,14 \%$ & $45 \%$ & $49,28 \%$ & $50 \%$ & $52,85 \%$ & $44,86 \%$ & Rendah \\
2 & $51,42 \%$ & $65,71 \%$ & $67,61 \%$ & $56,19 \%$ & $56,19 \%$ & $61,14 \%$ & Sedang \\
3 & $38,57 \%$ & $70 \%$ & $77,14 \%$ & $57,85 \%$ & $57,85 \%$ & $63,86 \%$ & Sedang \\
4 & $37,14 \%$ & $40 \%$ & $50,47 \%$ & $38,09 \%$ & $38,09 \%$ & $43,62 \%$ & Rendah \\
\hline $\begin{array}{c}\text { Seluruh } \\
\text { Indikator }\end{array}$ & $37,75 \%$ & $55,51 \%$ & $60,2 \%$ & $51,83 \%$ & $51,83 \%$ & $53,51 \%$ & Rendah \\
\hline
\end{tabular}


Berdasarkan tabel persentasi kemampuan pemecahan masalah siswa dengan mengacu pada indikator menurut Polya yaitu memahami masalah, merencanakan suatu penyelesaian, menyelesaikan masalah dan memeriksa kembali hasil yang diperoleh menunjukan bahwa kemampuan pemecahan masalah siswa di kelas IX berada pada kategori rendah.

\subsection{Pembahasan}

Penelitian ini bertujuan untuk menggambarkan kemampuan pemecahan masalah siswa pada materi bangun ruang sisi datar. Indikator pemecahan masalah menurut Polya yaitu yang memahami masalah, artinya siswa mampu menuliskan semua informasi yang ada pada soal. Indikator merencanakan suatu penyelesaian, artinya siswa mampu menuliskan rencana awal yang bisa berupa persamaan matematika ataupun rumus yang diperlukan dalam soal. Indikator menyelesaikan masalah, artinya siswa mampu menyelesaikan permasalahan matematika yang ditanyakan pada soal. Dan indikator terakhir yaitu memeriksa kembali hasil yang diperoleh, artinya siswa dapat mengecek kembali langkah-langkah pengerjaan yang mereka jawab apakah sudah sistematis.

Pada indikator pertama yaitu memahami masalah mendapat presentase dengan kategori rendah yaitu 44,86\%. Dari hasil ini dapat diketahui bahwa kemampuan siswa dalam memahami masalah yaitu dengan mengidentifikasi informasi-informasi dalam soal masih belum tergolong baik. Berdasarkam hasil wawancara, kurangnya kemampuan pada indikator ini disebabkan oleh siswa masih kurang paham menginformasi pada soal dalam bentuk matematika. Selain itu, hal ini terjadi karena siswa tidak memahami maksud dari soal sehingga tidak dapat menterjamahkan soal kedalam kalimatnya sendiri [17].

Untuk indikator kedua dan ketiga yaitu merencanakan suatu penyelesaian dan menyelesaikan masalah mendapat presentase $61,14 \%$ dan $63,86 \%$ berada pada kategori sedang. Hal ini disebabkan karena siswa tidak mengetahui rencana penyelesaian yang benar, siswa tidak mampu merencanakan penyelesaian karena terbiasa dengan langsung mengerjakan soal. Selain itu siswa kurang mampu memahami maksud dari soal sehingga tidak dapat menterjemahkan soal kedalam bahasa sendiri [10]. Sehingga skor pada indikator kedua ini berada pada kategori sedang. Kemudian untuk indikator menyelesaikan masalah, berada pada kategori sedang diakibatkan karena siswa kurang paham dengan materi yang diberikan sehingga tidak mampu dan tidak teliti dalam perhitungan menyelesaikan soal. Untuk indikator keempat yaitu memeriksa kembali hasil yang diperoleh mendapat presentase dengan kategori rendah sebesar $43,62 \%$. Hal ini dikarenakan siswa tidak terbiasa menggunakan langkah-langkah yang sistematis, dapat dilihat pada [8] bahwa kesalahan dalam memeriksa kembali hasil yang diperoleh disebabkan karena siswa beranggapan bahwa siswa merasa tidak perlu dalam melakykan pengecekan karena dia yakin bahwa jawaban yang diberikan sudah benar. Sehingga mereka tidak lagi memeriksa kembali hasil yang mereka kerjakan.

Kurangnya pemahaman siswa terhadap materi pelajaran merupakan salah satu faktor yang menyebabkan rendahnya kemampuan pemecahan masalah siswa. Dengan pemahaman siswa pada materi pelajaran yang minim dapat mengakibatkan siswa kesulitan dalam mengerjakan soal dengan benar. Terutama pada materi pelajaran bangun ruang sisi datar, yang terdiri dari beberapa bangun ruang yang akan dipelajari sehingga memerlukan pemahaman dengan teliti agar siswa mudah memahami isi 
materi. Pada materi ini jika guru benar-benar melatih siswa dengan soal-soal pemecahan masalah, siswa akan lebih paham lagi dengan isi materi, mengingat materi bangun ruang sisi datar terdapat banyak hal-hal yang bisa dikaitkan dengan keadaan lingkungan kehidupan sehari-hari sehingga mampu membantu siswa dalam mengerjakan soal dan siswa lebih mudah memahami maksud dari soal. Kemudian dalam menyelesaikan soal hendaknya guru perlu mendampingi dan memperhatikan apa yang dikerjakan oleh siswa. Guru hendaknya mengajarkan siswa menyelesaikan soal-soal dengan menggunakan langkah-langkah penyelesaian pemecahan masalah yang sistematis, yaitu salah satunya dengan langkah pemecahan masalah menurut polya memahami masalah, merencanakan penyelesaian, menyelesaikan masalah serta memeriksa kembali hasil yang diperoleh [18]. Dengan sendirinya siswa akan terbiasa mengerjakan soal-soal dengan langkah-langkah yang sistematis.

Rendahnya kemampuan pemecahan masalah matematis juga dapat dilihat dari siswa yang tidak bisa mengerjkan soal yang berbeda dari contoh soal yang diberikan oleh guru, siswa tidak memahami soal yang berbentuk soal cerita, siswa menjawab soal tidak menggunakan langkah-langkah pemecahan masalah. Pada hasil wawancara yang dilakukan dengan enam orang siswa yaitu dua orang siswa dengan nilai tinggi, dua orang siswa dengan nilai sedang dan dua orang siswa dengan nilai rendah menyatakan bahwa rata-rata dari mereka tidak memahami soal karena belum paham betul dengan materi bangun ruang sisi datar. Adapun langkah-langkah yang digunakan dalam mengerjakan soal tidak dijawab oleh siswa dengan teliti sehingga hasil yang mereka peroleh tidak maksimal. Sehingga karena hal ini, kemampuan pemecahan masalah siswa pada materi bangun ruang sisi datar masih berada pada kategori rendah.

\section{Kesimpulan}

Kemampuan pemecahan masalah siswa kelas IX di SMP N 2 Gorontalo sebesar 53,51\%, sehingga kemampuan pemecahan masalah siswa pada materi bangun ruang sisi datar berada pada kategori rendah yang berarti bahwa kemampuan siswa dalam mengerjakan soal dengan indikator pemecahan masalah masih perlu ditingkatkan lagi. Indikator pertama yaitu memahami masalah mendapat perolehan skor $44,86 \%$ yang dimana indikator ini tergolong rendah. Indikator kedua yaitu merencanakan penyelesaian mendapat perolehan skor sebesar $61,14 \%$, indikator kedua ini tergolong pada kategori sedang. Indikator ketiga yaitu menyelesaikan masalah mendapat perolehan skor $63,86 \%$ yang dimana indikator ini tergolong pada kategori sedang. Indikator memeriksa kembali hasil yang diperoleh mendapat perolehan skor sebesar $43,62 \%$ indikator terakhir ini tergolong pada kategori rendah.

\section{Referensi}

[1] Peraturan Menteri Pendidikan Nasional (PERMENDIKNAS) Republik Indonesia No. 22 tahun 2016.

[2] I. I. A. Ayubi, Erwanudin, dan M. Bernard, "Pengaruh Pembelajaran Berbasis Masalah Terhadap Kemampuan Pemecahan Masalah Matematis Siswa SMA", Jurnal Pembelajaran Matematika Inovatif, Vol. 1, No. 3, pp. 355-360, 2018.

[3] W. A. Lubis, S. Ariswoyo, dan E. Syahputra, "Kemampuan Pemecahan Masalah Matematika Melalui Pendekatan Pendidikan Matematika Realistik Dan Pendekatan Penemuan Terbimbing Barbantuan Autograph", EDUMATIKA: 
jurnal riset pendidikan matematika, Vol. 3, No. 1, pp. 1-12, 2020.

[4] N. P. R. Wulandari, N. Dantes, dan P. A. Antara, "Pendekatan Pendidikan Matematika Realistik Berbasis Open Ended Terhadap Kemampuan Pemecahan Masalah Matematika Siswa", Jurnal Ilmiah Sekolah Dasar, Vol. 4, No. 2, pp. 131142, 2020.

[5] K. A. Y. Pauweni and M. E. B. Iskandar, "Meningkatkan Kemampuan Pemecahan Masalah Matematika Melalui Model Problem-Based Learning pada Materi Bilangan Pecahan," Euler J. Ilm. Mat. Sains dan Teknol., vol. 8, no. 1, pp. 23-28, Apr. 2021, doi: 10.34312/euler.v8i1.10372.

[6] P. W. C. Davita, dan H. Pujiastuti, "Analisis Kemampuan Pemecahan Masalah Matematika Ditinjau Dari Gender", Jurnal Matematika Kreatif-Inovatif, Vol. 11, No. 1, pp. 110-117, 2020.

[7] F. Andayani, dan A. N. Lathifah, "Analisis Kemampuan Pemecahan Masalah Siswa SMP Dalam Menyelesaikan Soal Pada Materi Aritmatika Sosial", Jurnal Cendekia: Jurnal Pendidikan Matematika, Vol. 3, No. 1, pp. 1-10, 2019.

[8] P. Akbar, A. hamid, dan A. I. Sugandi, "Analisis Kemampuan Pemecahan Masalah Dan Disposisi Matematik Siswa Kelas XI SMA Putra Juang Dalam Materi Peluang", Jurnal Cendekia: Jurnal Pendidikan Matematika, Vol. 2, No. 1, pp. 144-153, 2018.

[9] K. Usman, I. Djakaria, dan S. Hasan. "Deskripsi Hasil Belajar Siswa Ditinjau Dari Kemampuan Pemecahan Masalah Matematika", Jurnal Karya Pendidikan Matematika, Vol. 8 No. 1, Universitas Negeri Gorontalo.

[10] Fariha dan Ramlah, "Analisis Kemampuan Pemecahan Masalalah Matematis Siswa Berdasarlkan Prosedur Polya", Jurnal Ilmiah Pendidikan Matematika, Vol. 6, No. 1, pp. 43-59, 2020.

[11] Z. Raudho, T. handayani, dan Syutarido, "Analisis Kemampuan Pemecahan Masalah Soal Pytagoras Berdasarkan Langkah-Langkah Polya", Suska Journal Of Mathematics Education, Vol. 6, No. 2, pp. 101-110, 2020.

[12] N. H. Astuti, A. Rusilowati, B. Subali dan P, Marwoto, "Analisis Kemampuan Pemecahan Masalah Model Polya Materi Getaran, Gelombang, Dan Bunyi Siswa SMP", Unnes Physics Education Journal, Vol. 9, No. 1, pp. 1-8, 2020.

[13] A. W. Abdullah, N. Achmad, and N. C. Fahrudin, "Deskripsi Hasil Belajar Matematika Siswa Melalui Pembelajaran Daring pada Pokok Bahasan Bangun Ruang Sisi Datar," Euler J. Ilm. Mat. Sains dan Teknol., vol. 8, no. 2, pp. 36-41, Dec. 2020, doi: 10.34312/euler.v8i2.10324.

[14] Rhilmadinar, M. Ramli, dan B. I. Ansari, "Efektifitas Modul Pembelajaran berbantuan Software Geogebra Pada Matri Bangun Ruang Sisi Datar", Jurnal Didaktik Matematika, Vol. 7, No. 2, pp. 142-155, 2020.

[15] P. Zakaria, N. Nurwan, and F. D. Silalahi, "Deskripsi Kemampuan Berpikir Kritis Siswa Melalui Pembelajaran Daring pada Materi Segi Empat," Euler J. Ilm. Mat. Sains dan Teknol., vol. 9, no. 1, pp. 32-39, Jun. 2021, doi: 10.34312/euler.v9i1.10539.

[16] V. Damopolii, N. Bito, and R. Resmawan, "Efektifitas Media Pembelajaran 
P. Unonongo, dkk | Analisis Kemampuan Pemecahan Masalah pada ...

berbasis Multimedia pada Materi Segiempat," Algoritm. J. Math. Educ., vol. 1, no. 2, pp. 74-85, 2019, doi: 10.15408/ajme.v1i1.

[17] Mayasari dan T. Rosyana, "Pengaruh Kemandirian Belajar Terhadap Kemampuan Pemecahan Masalah Matematis Siswa SMP Kota Bandung", Jurnal Cendekia: Jurnal Pendidikan Matematika, Vol. 3, No. 1, pp. 82-89, 2020

[18] R. J. Purnomo, S. A. Widodo, dan D. S. Setiana, "Profil Berpikir Siswa Dalam Memecahkan Masalah Matematis Berdasarkan Model Polya", Jurnal Pendidikan Matematika, Vol. 1, No. 2, pp. 101-110, 2020. 